\title{
INSULIN-LIKE GROWTH FACTORS IN THE SERUM OF PATIENTS WITH PAPILLARY THYROID CANCER
}

DOI: 10.36740/WLek202108126

\author{
Nataliia S. Pidchenko' , Mykola V. Krasnoselskyi', Nataliia A. Mitriaieva', Lidiya V. Grebenik', Olha M. Astapieva², \\ Ganna V. Grushka' ${ }^{2}$, Olga I. Paskevych' ${ }^{2}$, Yuliia Ya. Fedulenkova ${ }^{2}$, Mykhailo S. Myroshnychenko² \\ 'STATE ORGANIZATION «GRYGORIEV INSTITUTE FOR MEDICAL RADIOLOGY AND ONCOLOGY OF THE NATIONAL ACADEMY OF MEDICAL SCIENCES OF \\ UKRAINE», KHARKIV, UKRAINE \\ 2KHARKIV NATIONAL MEDICAL UNIVERSITY, KHARKIV, UKRAINE
}

\begin{abstract}
The aim is to study the level of insulin-like growth factor-1 (IGF-1) and insulin-like growth factor-2 (IGF-2) in the blood serum of patients with papillary thyroid cancer, depending on the main clinical and morphological features of the disease.

Materials and methods: The material was the information about 60 patients with papillary thyroid cancer (group 1). In group 2 there were 10 patients without oncopathology. All patients underwent clinical examination after total thyroidectomy before special treatment (radioiodine therapy): ultrasound diagnosis of the neck, confirmed diagnosis of papillary thyroid cancer by morphological examination of operative material. All patients underwent anthropometric studies (height, weight), on the basis of which the body mass index (BMI) was calculated. The study program also included determination of the level of thyroid-stimulating hormone of the pituitary gland (TSH), thyroglobulin (TG), antibodies to thyroglobulin (AB-TG). It was also determined the serum glucose level. In order to assess insulin resistance, the HOMA-IR index was calculated. All patients were tested for serum IGF-1 and IGF-2.

Results: In the blood serum of patients with papillary thyroid cancer in $63 \%$ of patients the level of IGF-1 and in $85 \%$ - IGF- 2 was probably higher than in the control group. There is a relationship between the level of IGF-1, IGF-2 and elevated level of proliferating factor - insulin in the serum of patients with papillary thyroid cancer. This may indicate an aggressive potential of the disease (i.e. clinical data on the prevalence of papillary thyroid cancer coincide with laboratory data). There was found a relationship between the expression of IGF-1, IGF-2 and insulin: at elevated levels of insulin $>24.9 \mu \mathrm{IU} / \mathrm{ml}$, IGF- 1 increases 4.2 times, and IGF- $2-2.5$ times. Evaluation of the relationship between the level of IGF-1 and IGF-2 and cervical lymph node involvement shows that in the absence of lesion (N0) there is an increase in these indicators by 2.2 and 1.8 times, respectively. Conclusions: The signaling system of insulin-like growth factors (IGF-1 and IGF-2) plays an important role in the occurrence and progression of malignant tumors. It is especially true for papillary thyroid cancer, so its components can be considered as potential diagnostic and prognostic markers of the disease and targets for anticancer therapy.
\end{abstract}

KEY WORDS: insulin-like growth factor-1, insulin-like growth factor-2, blood serum, papillary thyroid cancer

Wiad Lek. 2021;74(8):1925-1930

\section{INTRODUCTION}

Over the past few decades, there has been an increase in the incidence of thyroid cancer, and the rate of this growth is higher than any other cancers. However, mortality from thyroid cancer remains relatively stable $[1,2]$. Although it is a less dangerous form of cancer against many other malignancies, the social and economic consequences of increasing incidence of thyroid cancer are obvious [3]. Interestingly, the increasing incidence of thyroid cancer is caused mainly by a growing number of cases of papillary histological variants. However, the growth of follicular or medullary subtypes is observed in a much smaller number of cases [4]. According to various data, the share of papillary thyroid cancer is from $56 \%$ to $76 \%$ of all types of malignant neoplasms of the thyroid gland $[5,6]$. This histological subtype of thyroid neoplasms is dangerous due to the very gradual development, a long time latent course, which often causes accidental detection [7].

In Ukraine, we see an increasing incidence of thyroid cancer: more than 2 thousand new cases of this pathology are diagnosed annually [8]. The incidence of thyroid cancer was $4.3 \%$ of total endocrine morbidity in 2018 [9]. All this is worrying and makes the problem of detection and treatment of malignant thyroid tumors very relevant both in the world, and in Ukraine.

Identification of various molecular mechanisms of tumor growth is one of the promising approaches in the individualization of diagnosis and treatment of patients with thyroid cancer. Today, we have a concept of the formed signaling pathway which includes IGF-1, IGF-2 and IGF-1 receptor type [10]. IGF-1 and IGF-2 are mitogenic peptides, highly homologous to each other and insulin. This system is regulated at the cellular and tissue levels by six proteins that bind insulin-like growth factor and the proteinases that break them down. IGFs are synthesized in the liver and some other tissues under the influence of somatotropic hormone of the pituitary gland [11]. Nevertheless, they can also be synthesized by cells of various tumors and act as auto/paracrine mediators of the growth, metastasis and antiapoptotic responses of malignant cells [12]. 
To date, some studies have found that aberrant IGF signaling is critical in the pathogenesis and progression of cancer. It was found an increased expression of ligands and IGF receptors in tumors of the breast, lung, pancreas, colon, prostate, ovary and thyroid gland, while there was an association with an unfavorable prognosis [13-15]. Scientists have proved participation of IGF in apoptosis, transformation, invasion and metastasis of tumor cells. At the same time, the role of IGF in circulating peripheral blood in papillary thyroid cancer is insufficiently studied.

\section{THE AIM}

The aim was to study the level of IGF- 1 and IGF- 2 in the blood serum of patients with papillary thyroid cancer, depending on the main clinical and morphological features of the disease.

\section{MATERIALS AND METHODS}

The material was the information about 60 patients with papillary thyroid cancer aged 24 to 77 years (median $48.9 \pm 1.6$ ),

Table I. The distribution of patients with papillary thyroid cancer according to the TNM classification.

\begin{tabular}{ccc}
\hline TNM & Absolute number & Relative number (\%) \\
\hline $\mathrm{T}_{1} \mathrm{~N}_{0} \mathrm{M}_{0}$ & 30 & 50 \\
\hline $\mathrm{T}_{2} \mathrm{~N}_{0} \mathrm{M}_{0}$ & 7 & 12 \\
\hline $\mathrm{T}_{3} \mathrm{~N}_{0} \mathrm{M}_{0}$ & 2 & 3 \\
\hline $\mathrm{T}_{4} \mathrm{~N}_{0} \mathrm{M}_{0}$ & 0 & 0 \\
\hline $\mathrm{T}_{1} \mathrm{~N}_{1 \mathrm{a}} \mathrm{M}_{0}$ & 8 & 13 \\
\hline $\mathrm{T}_{1} \mathrm{~N}_{1 \mathrm{~b}} \mathrm{M}_{0}$ & 1 & 2 \\
\hline $\mathrm{T}_{2} \mathrm{~N}_{1 \mathrm{a}} \mathrm{M}_{0}$ & 4 & 7 \\
\hline $\mathrm{T}_{2} \mathrm{~N}_{1 \mathrm{~b}} \mathrm{M}_{0}$ & 1 & 2 \\
\hline $\mathrm{T}_{3} \mathrm{~N}_{1 \mathrm{a}} \mathrm{M}_{0}$ & 5 & 8 \\
\hline $\mathrm{T}_{3} \mathrm{~N}_{1 \mathrm{~b}} \mathrm{M}_{0}$ & 2 & 3 \\
\hline $\mathrm{Total}_{0}$ & 60 & $100 \%$ \\
\hline
\end{tabular}

treated at State Organization "Grygoriev Institute for Medical Radiology and Oncology of the National Academy of Medical Sciences of Ukraine" in the period 2019-2020.

According to the Helsinki Declaration of the World Medical Association "Ethical principles of medical research with human participation as the object of study" (1964-2013), all patients were informed about the purpose, methods of research and gave their written consent to participate in the study. The research protocols were approved by the Committee on Bioethics and Deontology at State Organization "Grygoriev Institute for Medical Radiology and Oncology of the National Academy of Medical Sciences of Ukraine".

All patients underwent clinical examination after total thyroidectomy before special treatment (radioiodine therapy): ultrasound diagnosis of the neck, confirmed diagnosis of papillary thyroid cancer by morphological examination of operative material.

All patients were divided into 2 groups: 1 - 60 patients with papillary thyroid cancer, $2-10$ patients without oncopathology.

Patients in group 1 were distributed by stages of the tumor process according to the TNM system according to the International TNM classification of malignant neoplasms [16]. There were 30 patients (50\%) with stage $\mathrm{T}_{1} \mathrm{~N}_{0} \mathrm{M}_{0}, 7$ patients (12\%) with tumor size from 2 to $4 \mathrm{~cm}$ (stage $\mathrm{T}_{2} \mathrm{~N}_{0} \mathrm{M}_{0}$ ), patients with extrathyroid spread of thyroid cancer (metastasis to lymph nodes on one side -8 patients $(13 \%)$ with $\mathrm{T}_{1} \mathrm{~N}_{12} \mathrm{M}_{0}$, 4 patients (7\%) with $\mathrm{T}_{2} \mathrm{~N}_{1 \mathrm{a}} \mathrm{M}_{0}, 5$ patients (8\%) with $\mathrm{T}_{3} \mathrm{~N}_{1 \mathrm{a}} \mathrm{M}_{0}$ ). Patients with lesions of the cervical lymph nodes on both sides distributed as follows: $\mathrm{T}_{1} \mathrm{~N}_{1 \mathrm{~b}} \mathrm{M}_{0}-1$ patient, $\mathrm{T}_{2} \mathrm{~N}_{1 \mathrm{~b}} \mathrm{M}_{0}-$ 1 patient, $\mathrm{T}_{3} \mathrm{~N}_{1 \mathrm{~b}} \mathrm{M}_{0}-2$ patients (totally 4 patients (7\%). Their distribution in group 1 by tumor size and presence or absence of cervical metastases is given in table I. That is, the majority of patients had the first and second stages of the disease (75\%). No patient in this group had distant pulmonary or bone metastases. 21 (35\%) patients had extrathyroid spread of thyroid cancer. Moreover, unilateral lesions of the

Table II. Clinical and laboratory characteristics of the patients of group 1.

\begin{tabular}{|c|c|c|c|c|}
\hline Parameter & Min & Max & $M \pm m$ & Median \\
\hline Weight, kg & 50.0 & 142.0 & $81.2 \pm 2.4$ & 79.5 \\
\hline Height, sm & 150.0 & 191.0 & $164.0 \pm 1.1$ & 162.0 \\
\hline BMI & 18.2 & 53.5 & $30.3 \pm 0.9$ & 30.0 \\
\hline Age (years) & 24.0 & 77.0 & $48.9 \pm 1.6$ & 47.5 \\
\hline AB-TG (IU/ml) & 10.2 & 1189.0 & $126.0 \pm 33.1$ & 21.0 \\
\hline TG (ng/ml) & 0.1 & 144.3 & $41.2 \pm 18.7$ & 10.0 \\
\hline $\mathrm{TSH}(\mu \mathrm{lU} / \mathrm{ml})$ & 4.8 & 98.4 & $60.8 \pm 3.3$ & 56.4 \\
\hline Glucose (mmol/l) & 4.0 & 8.0 & $5.3 \pm 0.1$ & 5.2 \\
\hline Insulin $(\mu \mathrm{IU} / \mathrm{ml})$ & 3.2 & 41.1 & $14.0 \pm 1.2$ & 10.4 \\
\hline HOMA-IR index & 0.6 & 10.2 & $3.4 \pm 0.3$ & 2.6 \\
\hline C-peptide (ng/ml) & 0.7 & 6.4 & $2.8 \pm 0.2$ & 2.6 \\
\hline Glycated hemoglobin (\%) & 4.6 & 6.9 & $5.4 \pm 0.1$ & 5.4 \\
\hline Blood calcium (mmol/l) & 1.8 & 2.7 & $2.3 \pm 0.1$ & 2.4 \\
\hline
\end{tabular}


Table III. The level of IGF-1 and IGF-2 in the blood serum of patients of group 1 and 2.

\begin{tabular}{ccccc}
\hline Group number & $\mathbf{n},(\%)$ & IGF-1, $\mathbf{n g} / \mathbf{m l}$ & $\mathbf{n},(\%)$ & IGF-2, $\mathbf{n g} / \mathbf{m l}$ \\
\hline \multirow{2}{*}{1} & $39(65)$ & $57.1^{*}(53.1-64.5)$ & $51(85)$ & $322.4^{*}(310.6-341.5)$ \\
\cline { 2 - 5 } & $21(35)$ & $19.1(18.4-24.2)$ & $9(15)$ & $96.1(94.5-100.2)$ \\
\hline 2 & $10(100)$ & $21.5(16.8-22.3)$ & $10(100)$ & $102,5(95.1-112.2)$ \\
\hline
\end{tabular}

Note: * - significance of differences of parameter between group 2 and group 1

Table IV. The level of IGF-1 and IGF-2 in the blood serum of patients with papillary thyroid cancer depending on the clinical and morphological characteristics of the disease

\begin{tabular}{|c|c|c|c|c|}
\hline \multirow{2}{*}{ Group number/Parameter } & \multicolumn{2}{|c|}{ IGF-1, ng/ml } & \multicolumn{2}{|c|}{ IGF-2, ng/ml } \\
\hline & $\mathbf{n}$ & Median & $\mathbf{n}$ & Median \\
\hline 2 & 10 & 21.5 & 10 & 102.5 \\
\hline 1 & 39 & $57.1^{*}$ & 51 & $322.4 *$ \\
\hline \multicolumn{5}{|c|}{ Age (years) } \\
\hline Till 40 & 14 & $41.3^{*}$ & 14 & $299.2^{*}$ \\
\hline $40-60$ & 13 & $81.5^{*} \#$ & 21 & $369.6^{*}$ \\
\hline$>60$ & 12 & $47.7^{*}$ & 16 & $283.7^{*}$ \\
\hline \multicolumn{5}{|c|}{ Sex } \\
\hline Men & 4 & $54.1^{*}$ & 7 & 403.2* \# \\
\hline Women & 35 & $82.0^{*} \#$ & 44 & $265.6^{*}$ \\
\hline \multicolumn{5}{|c|}{ BMI } \\
\hline $18.5-25$ & 5 & 36.4 & 10 & $217.7^{*}$ \\
\hline $25-30$ & 14 & $65.6^{*}$ & 15 & $422.2^{*} \#$ \\
\hline $30-35$ & 12 & $74.4^{*} \#$ & 17 & $350.4^{*}$ \\
\hline $35-40$ & 7 & 30.8 & 8 & $217.7^{*}$ \\
\hline$>40$ & 1 & 33.0 & 1 & $262.0^{*}$ \\
\hline \multicolumn{5}{|c|}{ HOMA-IR index } \\
\hline Till 2.77 & 18 & $46.9^{*}$ & 29 & $287.5^{*}$ \\
\hline$>2.77$ & 21 & $66.2^{*}$ & 22 & $366.8^{*}$ \\
\hline \multicolumn{5}{|c|}{ Insulin } \\
\hline Till 24,9 $\mu \mathrm{lU} / \mathrm{ml}$ & 35 & $42.6^{*}$ & 46 & $279.5^{*}$ \\
\hline$>24,9 \mu \mathrm{lU} / \mathrm{ml}$ & 4 & $180.2^{*} \#$ & 5 & 708.6* \# \\
\hline \multicolumn{5}{|c|}{ Lymph node involvement (N criterion) } \\
\hline $\mathrm{N}+$ & 21 & $39.7^{*}$ & 33 & $252.5^{*}$ \\
\hline $\mathrm{N}-$ & 39 & $86.7^{*} \#$ & 18 & $446.7^{*} \#$ \\
\hline \multicolumn{5}{|c|}{ TG } \\
\hline Till 10 ng/ml & 27 & $57.6^{*}$ & 50 & $309.4^{*}$ \\
\hline $10-50 \mathrm{ng} / \mathrm{ml}$ & 9 & $44.3^{*}$ & - & - \\
\hline$>50 \mathrm{ng} / \mathrm{ml}$ & 3 & 24.1 & 1 & $959.0^{*} \#$ \\
\hline \multicolumn{5}{|c|}{ AB-TG } \\
\hline Till $115 \mathrm{IU} / \mathrm{ml}$ & 30 & $55.5^{*}$ & 40 & $316.2^{*}$ \\
\hline$>115 \mathrm{IU} / \mathrm{ml}$ & 9 & $62.2^{*}$ & 11 & $344.4^{*}$ \\
\hline
\end{tabular}

Notes: ${ }^{*}$ - significance of differences between group 2 and group 1; \# - significance of differences in the group regarding the distribution of clinical and morphological parameters.

cervical lymph nodes were observed in 17 patients $(28.9 \%)$, bilateral lesions - in 4 (7\%) patients.

Group 2 consisted of 10 patients without cancer, who corresponded to the group 1 by age and sex.
All patients at the initial treatment underwent anthropometric studies (height, weight), on the basis of which the BMI was calculated according to the formula: $\mathrm{BMI}=$ body mass / height ${ }^{2}\left(\mathrm{~kg} / \mathrm{M}^{2}\right)$. 
BMI in both groups ranged from 18.2 to 53.5 (median 30.0).

The study program also included determination of the level of TSH, TG, AB-TG (test system BRAHMS Henning Berlin GMBH, Germany). Serum glucose level was determined by glucose oxidase method.

The author also determined the level of insulin in the blood serum (test system from Diagnostic System Laboratories, USA). In order to assess insulin resistance, the HOMA-IR index was calculated according to the formula:

HOMA-IR $=$ fasting glucose $(\mathrm{nmol} / \mathrm{L}) \times$ fasting insulin (microU/L) / 22.5.

Index value $>2.7$ indicated the presence of insulin resistance.

The obtained clinical data are shown in table II.

All patients were tested for serum IGF-1 and IGF-2. An enzyme-linked immunosorbent analysis (ELISA) was performed using the standard set of reagents "Human IGF-1 ELISA Kit" and "Human IGF-2 ELISA Kit" (Elabscience Biotechnology Inc., USA). Measurements were performed with a semi-automatic enzyme-linked immunosorbent analyzer "Immunochem-2100" (USA).

All patients were tested for serum IGF-1 and IGF-2 by enzyme-linked immunosorbent assay (ELISA) using the standard set of reagents "Human IGF-1 (Insulin-like Growth Factor 1) ELISA Kit" and "Human IGF-2 -like Growth Factor 2) ELISA Kit "by Elabscience Biotechnology Inc. USA ». Measurements were performed with a semi-automatic enzyme-linked immunosorbent assay "Immunochem-2100" (USA).

Statistical analysis of the data was performed using the statistical software package "Statistica" by non-parametric methods for small samples. In the absence of a normal distribution, the medians and quartiles (Me, Lq-Uq) were given in a row. The results were compared between groups, using the Mann-Whitney test. Discrepancies were considered statistically significant at $\mathrm{p}<0.05$.

\section{RESULTS AND DISCUSSION}

According to clinical data, 30 patients (50\%) had the first stage of the disease and no signs of metastasis. 7 patients $(12 \%)$ had the second stage of papillary thyroid cancer, 2 patients $(3 \%)$ - stage III. Thus, in 39 patients (75\%) of group 1 papillary thyroid cancer localized only in thyroid gland without metastasis. 21 patients (35\%) of group 1 had metastases of the cervical lymph nodes. Unilateral lesions of the cervical lymph nodes were found in 17 patients (28\%) and 4 patients (7\%) had bilateral metastatic lesions of the cervical lymph nodes.

Analysis of IGF-1 and IGF-2 levels in the serum of patients of group 1 and 2 showed that IGF-1 in $65 \%$ of patients in group I was 2.7 times higher than in group 2, in $35 \%$ of cases - was at the level of control values. The level of IGF-2 in $85 \%$ of patients in group 1 was 3.1 times higher than in group 1, while in $15 \%$ of patients in group 1 this parameter did not differ from the norm. The data are shown in table III.
Thus, a comparative analysis of IGF-1 and IGF-2 level in the blood serum of patients with papillary thyroid cancer (group 1) and almost healthy individuals (group 2) showed in most cases an increased level of IGF-1 and IGF-2 in patients with papillary thyroid cancer. According to the literature, the IGF signaling system plays an important role in carcinogenesis [16]. IGF-1 has proved to induce mitogen-activated protein kinase pathway, leading to inhibition of apoptosis through inactivation of one of the proapoptotic proteins, Bad [17]. An increased expression of IGF ligands and receptors indicates an unfavorable prognosis of the disease. The IGF system has been shown to contribute to thyroid carcinogenesis through the IGF-2/IR-A autocrine loop because IGF-2 activates the IR-A isoform, expressed in neoplastic thyrocytes, thereby ensuring their proliferation and inhibition of apoptosis. Thus, increasing level of IGF-1 and IGF-2 in the blood serum of most patients with papillary thyroid cancer indicates the role of these factors in the processes of carcinogenesis [18].

The level of IGF-1 and IGF-2 in the blood serum of patients with papillary thyroid cancer before special treatment after surgery, depending on the clinical and morphological characteristics of the disease are given in table IV.

As one can see from table 4, distribution of patients without metastases was homogeneous, mostly women (35 women vs. 4 men).

The levels of IGF-1 (63\%) and IGF-2 (85\%) were significantly higher in patients with papillary thyroid cancer compared with the group 2.

It is clear from table 4 that significant relationships between IGF-1 and IGF-2 levels with the HOMA-IR index, which characterizes insulin resistance, $T G$ with $A B-T G$ did not reveal. The author determined relationship between the expression of IGF-1, IGF-2 and insulin: at elevated levels of insulin $>24.9 \mu \mathrm{IU} / \mathrm{ml}$, IGF-1 increases 4.2 times, and IGF-2 -2.5 times.

Evaluation of the relationship between the level of IGF-1 and IGF-2 and cervical lymph node involvement showed that in the absence of lesion ( $\mathrm{N} 0$ ) there was an increase of these indicators by 2.2 and 1.8 times, respectively. Analysis of the distribution by BMI showed that the content of IGF-1 increased with BMI from 30 to 35, and IGF-2 - with BMI from 25 to 30 . The author has found that IGF-1 was 1.5 times higher in women than in men, and IGF-2, in contrast, was 1.5 times higher in men than in women. Patients aged 40 to 60 years also had a 1.7-fold increase in IGF-1 and a 1.2-fold increase in IGF-2.

Thereby, the signaling system of insulin-like growth factors (IGF-1 and IGF-2) plays an important role in the occurrence and progression of malignant tumors. It is especially true for papillary thyroid cancer, so its components can be considered as potential diagnostic and prognostic markers of the disease and targets for anticancer therapy. Our data coincide with clinical data about the influence of extrathyroid spread of papillary thyroid cancer on the course of thyroid cancer obtained earlier $[19,20]$. 


\section{CONCLUSIONS}

1. In $65 \%$ of patients with papillary thyroid cancer there was a lesion only within the thyroid gland, in $35 \%$ of patients the tumor process spread beyond the organ, in $28 \%$ of cases there were unilateral lesions of regional cervical lymph nodes, in $7 \%$ of cases - bilateral metastatic lesions.

2. In the blood serum of patients with papillary thyroid cancer in $63 \%$ of patients the level of IGF- 1 and in $85 \%$ - IGF-2 was probably higher than in the control group.

3. There is a relationship between the level of IGF-1, IGF-2 and elevated level of proliferating factor - insulin in the serum of patients with papillary thyroid cancer. This may indicate an aggressive potential of the disease (i.e. clinical data on the prevalence of papillary thyroid cancer coincide with laboratory data).

4. There was found a relationship between the expression of IGF-1, IGF-2 and insulin: at elevated levels of insulin $>24.9$ $\mu \mathrm{IU} / \mathrm{ml}$, IGF- 1 increases 4.2 times, and IGF- $2-2.5$ times. Evaluation of the relationship between the level of IGF-1 and IGF-2 and cervical lymph node involvement shows that in the absence of lesion (N0) there is an increase in these indicators by 2.2 and 1.8 times, respectively.

\section{REFERENCES}

1. Hershman JM. The increased incidence of thyroid cancer is worldwide. Clinical Thyroidology. 2017;29(1):11-12.

2. Chen W, Zheng R, Baade PD, Zhang S, Zeng H, Bray F, Jemal A, YuXQ, He J. Cancer statistics in China, 2015. CA: A Cancer Journal for Clinicians. 2016;66(2):115-132.

3. Lubitz CC, Kong CY, McMahon PM, Daniels GH, Chen Y, Economopoulos KP, Gazelle GS, Weinstein MC. Annual financial impact of well-differentiated thyroid cancer care in the United States. Cancer. 2014;120(9):1345-1352.

4. Liu Y, Su L, Xiao H. Review of factors related to the thyroid cancer epidemic. International journal of endocrinology. 2017;2017:5308635. doi: $0.1155 / 2017 / 5308635$

5. Lortet-Tieulent J, Franceschi S, Dal Maso L, Vaccarella S. Thyroid cancer «epidemic» also occurs in low- and middle-income countries. International Journal of Cancer. 2019;144(9):2082-2087. doi: 10.1002/ ij. 31884

6. Hershman JM. Thyroid cancer incidence and mortality are increasing. Clinical Thyroidology. 2017;29:221-223.

7. Dal Maso L, Panato C, FranceschiS, Serraino D, BuzzoniC, BuscoS, FerrettiS, Torrisi A, Falcini F, Zorzi M, Cirilli C, Mazzucco W, Magoni M, Collarile P, Pannozzo F, Caiazzo AL, Russo AG, Gili A, Caldarella A, Zanetti R, Michiara M, Mangone L, Filiberti RA, Fusco M, Gasparini F, Tagliabue G, Cesaraccio R, Tumino R, Gatti L, Tisano F, Piffer S, Sini GM, Mazzoleni G, Rosso S, Fanetti AC, Vaccarella S; for AIRTUM working group. The impact of overdiagnosis on thyroid cancer epidemic in Italy, 1998-2012. European Journal of Cancer. 2018;94:6-15.

8. Dovidnyk osnovnyh pokaznykiv dijalnosti endokrynologichnoi sluzhby Ukrainy za 2015 rik [The main indicators of the endocrinology service of Ukraine in 2015]. Endocrinology. 2016;21(1):1-38. (Ua)

9. Chukur 00. Dynamika zahvorjuvanosti j poshyrenosti patologii shhytopodibnoi zalozy sered doroslogo naselennja Ukrainy [Dynamics of morbidity and expansion of pathology of the thyroid gland among adult population of Ukraine]. Bulletin of social hygiene and health care organization of Ukraine. 2019;4:19-25. (Ua)
10. Bowers LW, Rossi EL, O'Flanagan CH, deGraffenried LA, Hursting SD. The role of the insulin/igf system in cancer: lessons learned from clinical trials and the energy balance-cancer link. Frontiers in Endocrinology (Lausanne). 2015;6:77. doi: 10.3389/fend0.2015.00077

11. Baxter, R.C. Igf binding proteins in cancer: mechanistic and clinical insights. Nature Reviews Cancer. 2014; 14: 329-341.

12. Weroha SJ, Haluska P. The insulin-like growth factor system in cancer. Endocrinology and Metabolism Clinics of North America. 2012;41(2): 335-350.

13. Ciampolillo A, De Tullio C, Giorgino F. The igf-i/igf-i receptor pathway: Implications in the pathophysiology of thyroid cancer. Current Medicinal Chemistry. 2005;12:2881-2891.

14. Vigneri PG, Tirro E, Pennisi MS, Massimino M, Stella S, Romano C, Manzella L. The insulin/igf system in colorectal cancer development and resistance to therapy. Frontiers in Oncology. 2015; 5:230. doi: 10.3389/ fonc.2015.00230

15. Simpson A, Petnga W, Macaulay VM, Weyer-Czernilofsky U, Bogenrieder T. Insulin-like growth factor (igf) pathway targeting in cancer: Role of the igf axis and opportunities for future combination studies. Targeted Oncology. 2017;12:571-597.

16. Bowers LW, Rossi EL, O'Flanagan CH, deGraffenried LA, Hursting SD. The Role of the Insulin/IGF System in Cancer: Lessons Learned from Clinical Trials and the Energy Balance-Cancer Link. Front Endocrinol (Lausanne). 2015; 6: 77. doi:10.3389/fend0.2015.00077

17. BrahmkhatriVP, Prasanna C, Atreya HS. Insulin-like growth factor system in cancer: novel targeted therapies. Biomed Research International. 2015;2015:538019. doi:10.1155/2015/538019

18. Zhang M, Liu J, Li M, Zhang S, L u Y, Liang Y, Zhao K, Li Y. Insulinlike growth factor 1/insulin-like growth factor 1 receptor signaling protects against cell apoptosis through the PI3K/AKT pathway in glioblastoma cells. Experimental and Therapeutic Medicine. 2018;16(2):1477-1482.

19. Vella $V$, Malaguarnera R. The emerging role of insulin receptor isoforms in thyroid cancer: clinical implications and new perspectives. International Journal of Molecular Sciences. 2018;19(12):3814. doi: 10.3390/ijms 19123814

20. Tkachenko GI, Vasyliyev LYa, Astapeva OM, Hrushka GV, Lukhovytska NI, Savchenko AS, Riyako VM. Bagatorichnyj dosvid likuvannja raku shhytopodibnoi zalozy v DU «Instytut medychnoi radiologii im. S.P. Grygor'jeva NAMN Ukrainy. [Long-term experience of thyroid cancer treatment at $\mathrm{SI}$ «Grigoriew institute for medical radiology of National Academy of Medical Sciences of Ukraine»]. Ukrainian Journal of Radiology. 2015.XXIII(2):183-185. (Ua).

\section{ORCID and contributionship:}

Nataliia S. Pidchenko: 0000-0002-4751-3650 A,D Mykola V. Krasnoselskyi: 0000-0001-5329-5533 ${ }^{A, E}$

Nataliia A. Mitriaieva: 0000-0001-7641-3133 ${ }^{B, F}$

Lidiya V. Grebenik: 0000-0001-7205-8939 C,E

Olha M. Astapieva: 0000-0003-1136-6131 ${ }^{B, D}$

Ganna V. Grushka: 0000-0002-3218-8541 A,F

Olga I. Paskevych: 0000-0002-9039-6250 ${ }^{F}$

Yuliia Ya. Fedulenkova: 0000-0001-8599-9500 ${ }^{B}$

Mykhailo S. Myroshnychenko: 0000-0002-6920-8374 ${ }^{D}$

\section{Conflict of interest:}

The Authors declare no conflict of interest. 


\section{CORRESPONDING AUTHOR}

Mykhailo S. Myroshnychenko

Pathological Anatomy Department,

Kharkiv National Medical University

str. Svetlaya 27A, apt. 70, 61129, Kharkiv, Ukraine

tel: +380501699763

e-mail:msmyroshnychenko@ukr.net

Received: 15.04 .2021

Accepted: 30.07.2021

A - Work concept and design, B - Data collection and analysis, C - Responsibility for statistical analysis,

D-Writing the article, $\mathbf{E}$ - Critical review, $\mathbf{F}$ - Final approval of the article 